\title{
Tax Compliance: An Experimental Approach
}

\author{
Kristian Agung Prasetyo \\ Pusdiklat Pajak Kementerian Keuangan \\ Suhut Tumpal Sinaga \\ Politeknik Keuangan Negara STAN
}

\begin{abstract}
In a self-assessment system, the tax office has a passive position. Their main duty of the tax office is to ensure that taxes that are calculated and paid by the taxpayers are in accordance with the applicable tax rules. The main instrument for this purpose is, in an income tax context, the income tax return. Based on the information written by taxpayers in this form, the tax office then conducts a set of activities to see of the tax return contains information that reflects taxpayer's reality.

The self-assessment system carries a consequence that taxpayer compliance has a major role in determining the amount of taxes that are collected by the tax office. If the taxpayers comply with the tax rules, then consequently, more tax revenue will be collected. On the contrary, if the compliance rate is low, then there will be less revenue.

This research looks at this issue. The focus is individual taxpayers as their contribution to the total revenue currently is low. For this purpose, this research uses an experimental approach using participants from students at the PKN STAN (from both school leavers and civil servants), tax trainers at the Pusdiklat Pajak, and newly-recruited employees of the tax office. The experiment reveals that firstly, on average the research participants report less income that it should have been reported. Secondly, it is revealed that audit rate and penalty rate are the two most important factors in influencing the amount of income reported by the research participants.
\end{abstract}

Keywords: Compliance; experiment; self assessment; tax.

\footnotetext{
*Corresponding author: Kristian Agung Prasetyo, email:kagungp@gmail.com ISSN: 2549-3221 (Print) 2549-323X (Online) DOI: http://doi.org/10.26487/hebr.v1i1.1162
} 


\section{Introduction}

Tax has an important role in Indonesia as most of national revenue is derived from taxation. In 2016 for instance, more than $86 \%$ of national revenue is based on taxation (BPS citation here). Unfortunately, since 2009, tax revenue is always lower that what is targeted at the national budget (Figure 1). The last time the target revenue is met was in 2008 possibly due to the sunset policy. Sunset policy is basically a limited-type of tax amnesty whereby some of the administrative penalty for unpaid taxes is forfeited.

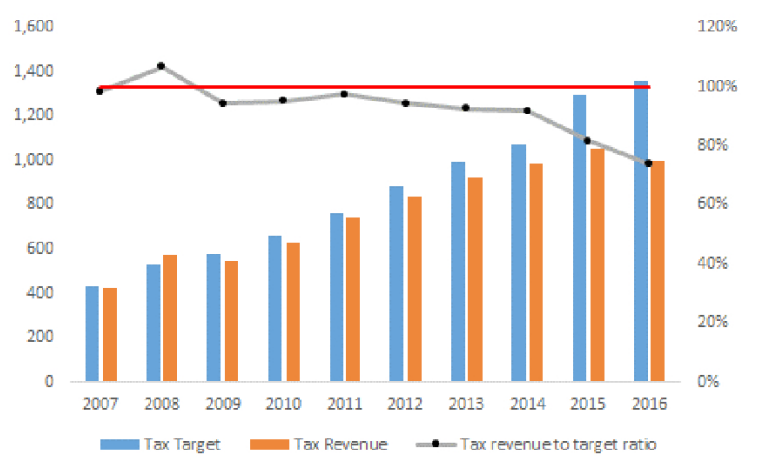

Figure 1 Revenue to target ratio
The main type of taxes administered by the central government in Indonesia includes income tax, value-added tax, sales tax on luxury goods, property tax, and stamp duty. The emphasis of this research is on the income tax paid by individuals. The reason for this is that although income tax carries the bulk of tax revenue, the contribution of individual income taxpayers is low (Table 1).

Indonesia uses the self-assessment system whereby taxpayers calculate, pay, and then report their tax payable. As a consequence, the taxation system relies on the honesty of taxpayers to comply with the tax rules when they fill in various information their tax return. This includes, among other things, the amount of taxable income.

The tax office has a mechanism to check the accuracy of what is reported by the taxpayers in their tax return. If it is found that a particular taxpayer fails to report the data accurately, then penalty will be applied. Otherwise, or if the tax office does not take actions against taxpayers' tax return (and this is normally the

Table 1 Low contribution of income tax (individuals)

\begin{tabular}{lllll}
\hline Tax Type & Amount & & \multicolumn{2}{c}{ Proportion (\%) } \\
& 2014 & 2015 & 2014 & 2.15 \\
\hline Income tax on oil & $30,327.49$ & $12,007.62$ & 5.55 & 6.00 \\
Income tax on natural gas & $57,118.05$ & $38,101.25$ & 10.45 & 0.35 \\
Income tax on natural gas (other) & 0.01 & 0.07 & 0.00 & 0.00 \\
Income tax (article 21) & $105,625.44$ & $114,428.23$ & 19.33 & 19.06 \\
Income tax (article 22) & $7,256.14$ & $8,484.65$ & 1.33 & 1.41 \\
Income tax (article 22 on importation) & $39,453.73$ & $40,252.35$ & 7.22 & 6.70 \\
Income tax (article 23) & $25,535.47$ & $28,121.53$ & 4.67 & 4.68 \\
Income tax (article 25/29, individuals) & $4,704.41$ & $8,992.42$ & 0.86 & 1.50 \\
Income tax (article 25/29, body corporate) & $148,719.21$ & $184,295.30$ & 27.21 & 30.69 \\
Income tax (article 26) & $34,728.02$ & $43,113.29$ & 6.35 & 7.18 \\
Income tax (borne by the government) & $5,655.30$ & $2,328.79$ & 1.03 & 0.39 \\
Income tax (final) & $87,318.12$ & $120,113.94$ & 15.98 & 20.00 \\
Income tax (other) & 88.82 & 189.39 & 0.02 & 0.03
\end{tabular}


case), then the information contained in the tax return is deemed to be true. It is therefore can be seen that in the current taxation system, it is taxpayers, rather than the tax office, who play a major role. The more compliant they are, the higher the tax revenue would be.

It is unfortunate that while taxpayer's compliance is of importance, their compliance level is however relatively unknown, particularly in the Indonesian context. This research is therefore aimed at addressing this issue focusing on individual income taxpayers mainly due to their low contribution, as identified earlier (Table 1). In this context, this research focuses only on taxable income. This is because in a self-assessment system, the calculation of taxable income is conducted by the taxpayers. As a result, they have the opportunity to under report their income, particularly those who are not subject extensive withholding mechanism.

An under reporting is seen by the law as a criminal offence. According to Becker, a criminal offence generally is affected by the probability of detection, the severity of penalty, and other factor. Becker believes that criminal offenders act rationally. This means that they choose an action that carries more benefit. As a consequence, a wrongdoing will not be taken place if the risk of being detected and the penalty rate is high.

In the taxation context, Allingham and Sandmo assert that taxpayers can choose to:

1. report all of their taxable income and pay the tax payable in full.

2. report some of their income and pay less tax.

If the second option is taken, and the tax office does not take any action, then the taxpayers will enjoy higher after tax income as opposed to the first alternative. However, if this action is detected by the tax office, then they will have lower after tax income as they have pay penalty in addition to the unpaid tax.

The amount of reported income is therefore increases when the applicable penalty rate or the probability of detection rises. As for income, if a taxpayer is riskaverse, then the higher their income is the higher the amount of their reported income will be. By contrast, if a taxpayer is a risk taker, the more money they have will only result in a lesser reported income. Similar effects also apply for tax rate because a higher tax rate provides an incentive for risk takers to lower their reported income. Here, the benefit of being non-compliant is the tax saving on the unreported income, whereas the cost is the risk of being detected and the penalty to be levied (Gruber, 2012).

In line with Becker's account, then taxpayers decide to be non-compliant if they see the benefit outweigh the cost. As an example, a taxpayer obtains a tax benefit of Rp 15 million if he decides not to report an income of $\mathrm{Rp} 100$ million (tax rate $=30 \%)$. If the government increases tax rate to $30 \%$, perhaps as an effort to tackle a decrease of revenue due to rampant non-compliance, then his saving rises to $\mathrm{Rp} 30$ million. This pushes $\mathrm{MB}_{1}$ to $\mathrm{MB}_{2}$, indicating a lower amount of unreported income (from A to C). By contrast, if the tax office decides to tighten its law enforcement activities, it increases the probability of detection, resulting in more taxpayers being apprehended and ultimately penalised. This shifts $M_{1}$ to $M_{2}$ thereby reduce the amount of unreported income from A to B (Figure 2). 


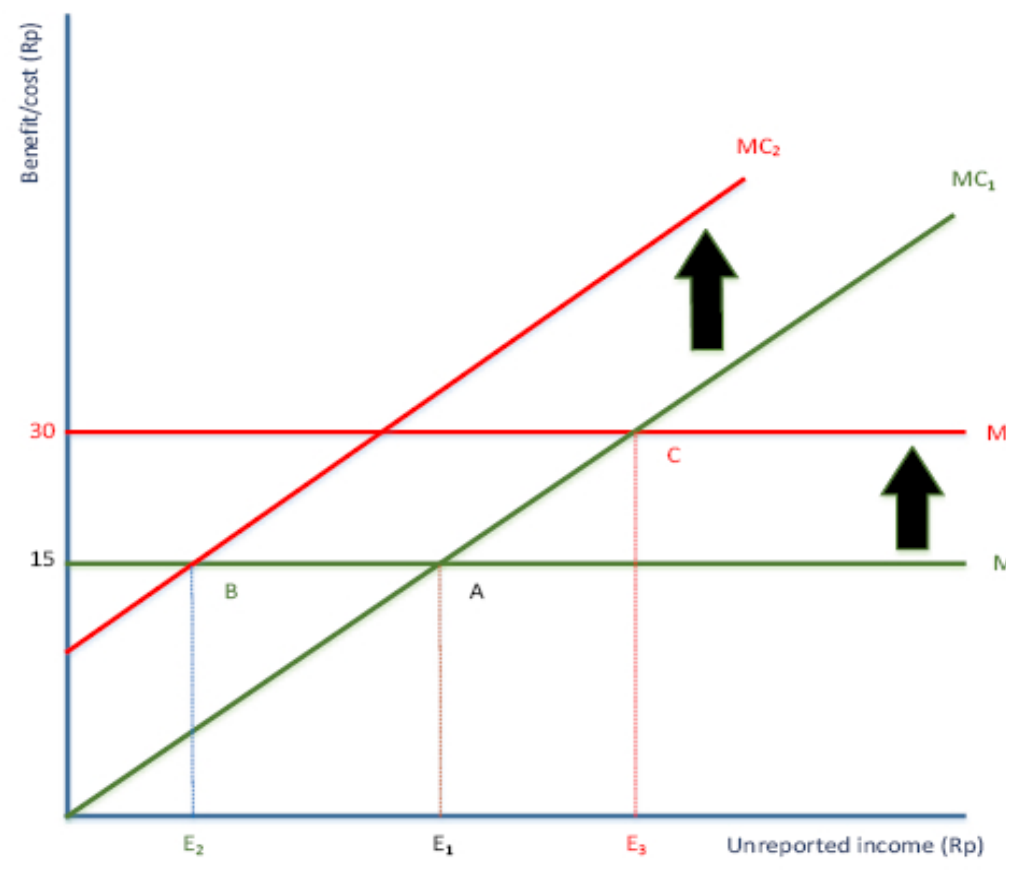

Figure 2 Tax evasion model

Empirical findings seem to be consistent with this, as summarised by Alm, McClelland, dan Schulze (1992) as follows:

1. Empirical findings

a. Audit probability is positively correlated with reported income.

b. Tax rate is negatively correlated with reported income.

c. Real incomeis positively correlated with reported income.

d. Compliance rate tend to be lower for non-married, younger, and self-employed taxpayers.

2. Experimental findings

a. Audit probability is positively correlated with reported income.

b. An increase in penalty rate only slightly increases compliance.

c. Tax rate does not have significant effect on reported income.

d. Real incomeis positively correlated with reported income.

e. Older or female taxpayers tend to be more compliant.

As for education, Birch, Peters and Sawyer (2003) argue that it is positively correlated with income although Juanda (2010) claims that undergraduate students tend to have higher compliance rate compared to post graduate students. In a different tone, in this context, Tan and Chin-Fatt (2003) believe that education does not have a significant effect on compliance.

In an experimental study, Juanda (2010) also reports that the higher a taxpayer's the income is, the lower their compliance will be. This is confirmed by Prasetyo (2011), based in his analysis on income tax returns, who reports that the higher the income of a taxpayer is, the lower their compliance will be. Prasetyo (2011) also reports that self-employed taxpayers tend to be less compliant compared to employed taxpayers, which is consistent with findings reported by Wallschutzky (1988). In is also interesting in this context to note what is reported by Slemrod, Blumenthal and Christian (2001) where high-wealth taxpayers, contrary to low-income taxpayers, will likely be less compliant if they receive a notice that they will be 
subject to an audit. Tax rate basically also shows similar pattern, where some researchers, such as Vogel (1972) and Clotfelter (1983), believe that an increase in tax rate reduces compliance while others, such as Wahlund (1993), argues that it does not have a significant effect on tax evasion.

Juanda (2010) also reports that an audit probability positively correlated with compliance level, which normally is the case (Marriott et al, 2013). In this context, it is important to note the type of taxpayers that are subject to audit. Here, Gemmell and Ratto (2012) found an evidence that if compliant taxpayers are subject to audit, then their compliance in the future would potentially decrease. On the contrary, if non-compliant taxpayers are subject to audits, their future compliance increases.

Another factor influencing taxpayer compliance is the severity of penalty. Although theoretically an increase in penalty improve compliance, its effect may be small (Arandse, 2010). Similarly, Marriott et al (2013) also report that audit probability and penalty are not significant in improving taxpayer compliance. In fact, increasing penalty may make compliance worsen (Gneezy and Rustichini, 2000).

This research, in essence, endeavours to see how those factors work in an Indonesian context. It seeks to answer the following questions:

1. In average, what is the percentage of income reported by the taxpayers?
2. What are the effect of tax rate, penalty rate, income, and audit probability on reported income?

\section{Method}

To answer the said questions, this research uses an experimental approach. This approach is taken because it enables the researchers to separately analyse the effect of a certain variable and to obtain sensitive information at a lower cost (Libby, Bloomfield, \& Nelson, 2002). However, it carries a weakness that as the experiment participants are normally students, the results may fail to adequately represent the population. In other words, the results may be difficult to generalise to the intended population, as addressed by Marriott (2013) and previously by Giridharadas (2010) for a different context. Druckman and Kam (2011) however argue that the result of an experiment with students as the participants are not significantly different to those that use 'real people.'

In the taxation context, the tax experiment conducted by Marriott, Randal, and Holmes (2013) that uses real taxpayers as participants shows similar result to those that use students as participants as summarised by Alm, McClelland, and Schulze (1992). This is probably the reason why most experimental research uses students as research participants (Marriott, Randal, and Holmes, 2012).

In this regard, this research uses a combination of students and non-

Table 2 Research participants

\begin{tabular}{cccc}
\hline No & Participants & Type & Number \\
\hline 1 & D3 (accounting) & Students & 37 \\
2 & D3 (taxation) & Students & 30 \\
3 & D4 (accounting) & Employee (tax office, old recruit) & 36 \\
4 & Training participants & Employee (tax office, new recruit) & 36 \\
5 & Tax trainers & Employee & 18 \\
\hline Total & & & 157 \\
\hline
\end{tabular}


students as research participants.

Each participant is given money at the sum of $\mathrm{Rp} 100$ thousand at the beginning of the game and are requested to play nine different games (Table 3). The amount of money to be kept at the end of the game depends on their response for each game.

Table 3 Game details

\begin{tabular}{|c|c|c|c|}
\hline No & Item & Value & \\
\hline \multirow[t]{4}{*}{1} & Taxable income (per annum) & Rp 200.000.000,00 & Control game \\
\hline & Penalty rate & $50 \%$ & \\
\hline & Tax rate & $25 \%$ & \\
\hline & Participants to be audited & 5 participants & \\
\hline \multirow[t]{4}{*}{2} & Taxable income (per annum) & Rp 100.000.000,00 & Income decreases \\
\hline & Penalty rate & $50 \%$ & \\
\hline & Tax rate & $25 \%$ & \\
\hline & Participants to be audited & 5 participants & \\
\hline \multirow[t]{4}{*}{3} & Taxable income (per annum) & Rp 300.000.000,00 & Income increases \\
\hline & Penalty rate & $50 \%$ & \\
\hline & Tax rate & $25 \%$ & \\
\hline & Participants to be audited & 5 participants & \\
\hline \multirow[t]{4}{*}{4} & Taxable income (per annum) & Rp 200.000.000,00 & Tax rate decreases \\
\hline & Penalty rate & $50 \%$ & \\
\hline & Tax rate & $5 \%$ & \\
\hline & Participants to be audited & 5 participants & \\
\hline \multirow[t]{4}{*}{5} & Taxable income (per annum) & Rp 200.000.000,00 & Tax rate increases \\
\hline & Penalty rate & $50 \%$ & \\
\hline & Tax rate & $50 \%$ & \\
\hline & Participants to be audited & 5 participants & \\
\hline \multirow[t]{4}{*}{6} & Taxable income (per annum) & Rp 200.000.000,00 & Penalty rate decreases \\
\hline & Penalty rate & $25 \%$ & \\
\hline & Tax rate & $25 \%$ & \\
\hline & Participants to be audited & 5 participants & \\
\hline \multirow[t]{4}{*}{7} & Taxable income (per annum) & Rp 200.000.000,00 & Penalty rate increases \\
\hline & Penalty rate & $100 \%$ & \\
\hline & Tax rate & $25 \%$ & \\
\hline & Participants to be audited & 5 participants & \\
\hline \multirow[t]{4}{*}{8} & Taxable income (per annum) & Rp 200.000.000,00 & Audit probability decreases \\
\hline & Penalty rate & $50 \%$ & \\
\hline & Tax rate & $25 \%$ & \\
\hline & Participants to be audited & 1 participant & \\
\hline \multirow[t]{4}{*}{9} & Taxable income (per annum) & Rp 200.000.000,00 & Audit probability increases \\
\hline & Penalty rate & $50 \%$ & \\
\hline & Tax rate & $25 \%$ & \\
\hline & Participants to be audited & 7 participants & \\
\hline
\end{tabular}


Several aspects need to be noted in Table 3. Firstly, the tax rate in this experiment does not use the progressive income tax rate stipulated in the income tax legislation for simplicity reason. This is because not every participant is familiar with the rules that stipulate how tax is calculated. Secondly, the participants to be audited are selected at random. In reality, the tax office uses certain criteria similar purpose. This research, however, is interested in the change in behaviour if the audit probability changes and this is best captured using random selection. Lastly, the number of participants to be audited seems to be large. In reality, the number of taxpayers who are subject to such audit is much smaller (less than 1\%). The focus of this research is on the behavioural change if the audit probability is changed. As such, the emphasis is on the direction of the change, as opposed to the number of the taxpayers who are subject to audits.

In order to achieve this, the research participants are requested to play the game scenario in Table 3 starting from game number 1 and see the researchers as the tax officials. The participants are given a card showing their amount of taxable income for a particular year ( $R p$ 200 million for game number 1). One colour-coded card is given for each game. They were then requested to write the number of income that they are going to report, the amount income tax that they have to pay, and the remaining income available for them (taxable income less income tax). The participants are also requested that:

1. They are free to decide the amount that they are willing to report. This means they can report their whole income or no income at all. This carries a consequence that it is possible for a participant to leave the research room with the full amount of money allocated to him/her. As an example, if a taxpayer reports no income, then he/she could leave the research room with a full income of $\mathrm{Rp} 200$ million. However, if that participant decides a full disclosure, then he/she will have a net income of $\mathrm{Rp} 150$ million. The ratio of the income reported and the actual taxable income is then calculated using the following formula:

$$
\text { Ratio }=\frac{\text { Reported income }}{\text { Actual income }} \times 100 \%
$$

2. The researchers will select research participants who are subject to audit at random. If a particular participant is selected to audit, that participant's card will be separated and be seen if the reported income is less than the taxable income. If so, that participant will be subject to penalty and must pay the unpaid tax. As an example, a participant who reports an income of $\mathrm{Rp} 40$ million will be required to pay the unpaid income tax of Rp 40 million (being the difference between Rp 150 million that he/she should have been paid and $\mathrm{Rp} 10$ million that he/she actually pays) and a penalty of $\mathrm{Rp} 20$ million (being $50 \%$ of the unpaid tax of $\operatorname{Rp} 40$ million). In the end, that participant will have a net income of $\mathrm{Rp} 130$ million (being $\mathrm{Rp}$ 200 million less $\mathrm{Rp} 10$ million of tax that he/she pays, less $\mathrm{Rp} 40$ million of unpaid tax, and less Rp 20 million of penalty), which is lower compared to the amount of money that he/she reports his/her full income.

3. After finish playing game number 9, participants are given sum of money as a result of participating in the research. The total of money that is given to a participant is based on the average of that participant's net income from all nine games that he/ 
she played. As a result, the more net income that he/she obtains, the more money that he/she receives at the end of the game.

4. A specialised database application based on Microsoft Access was created to manage the data obtained from the experiment. This includes data recording, the calculation of tax payable, the ration of reported income to taxable income, penalty applicable, net income, and money to be paid at the end of the game. SPSS version 23 is also used to perform some statistical analysis.

\section{Analysis and Discussion}

\section{Reported Income}

Based on game number 1 , it is revealed that the research participants only report on average Rp 166 million from Rp 200 million that should have been reported. This means they only report $83 \%$ of their actual taxable income (Table 4).

Table 4 reveals that participants from D4 accounting students on average report lower income compared to participants from other groupsalthough the difference is not significant $(\alpha=0.05)$. These participants are employees of Ministry of Finance and mostly have good understanding of tax laws. Those who are from the tax office are in fact familiar with tax minimising schemes. They also know that in practice, it is unlikely that a taxpayer will be subject to an audit. As such, it is possible that they are more confident in under reporting their income. This may cause their ratio in reported income lower than the rest of the participants.

A different situation is faced by tax trainers. Although they also have a good understanding on the operation of tax laws, their average reported income is higher. This is possibly because of the fact that most of their students are from the tax office. As such, there seems to be a reluctance in evading taxes due to their nature as trainers that are required to set examples to their students.

On the other hand, research participants who are from training participants show the highest level of reported income. As indicated earlier, they are newly-recruited employees of the tax office mostly from fresh graduates with minimal exposure to taxation laws. As such, they show a behaviour that is similar to the D3 (accounting) students.

These results are largely similar to what is reported by Juanda (2010) where participants from higher education level show lower compliance. However, Juanda (2010) does not have an account on the compliance level of newly-recruited tax officers. As Table 4 has shown, participants from newlyrecruited tax officers have higher compliance compared to participants from more experienced employees (D4 students).

Table 4 Ratio of reported income

\begin{tabular}{cccccc}
\hline \multirow{2}{*}{ No } & \multirow{2}{*}{ Participants } & Mean & \multicolumn{2}{c}{ Confidence Interval } & Standard \\
& & & Lower & Upper & deviation \\
\hline 1 & D4 (accounting) & .70208 & .58140 & .82277 & .356690 \\
2 & D3 (accounting) & .86676 & .80635 & .92717 & .181181 \\
3 & Tax trainers & .85694 & .73817 & .97572 & .238840 \\
4 & Training participants & .94819 & .90864 & .98774 & .116889 \\
5 & D3 (taxation) & .79667 & .67419 & .91914 & .327986 \\
& Overall & .83315 & .79056 & .87575 & .270199 \\
\hline
\end{tabular}




\section{Factors Influencing Compliance}

Several factors identified in the literature that are important in influencing taxpayer compliance are analysed in this research with results shown in Table 5 .

Table 5 and particularly Figure 3 show that the research participants report
The participants report more income when the penalty rate is increased and accordingly, they lower their reported income when penalty rate is reduced, a result that is generally consistent with what is predicted by Allingham and Sandmo (1976). This provides an indication that penalty rate can be used as an effective tool to tackle non-compliant

Table 5 Game results

\begin{tabular}{lccccc}
\hline \multirow{2}{*}{ No } & Factors & Mean & Std. Deviation & \multicolumn{2}{c}{ Confidence Interval } \\
& & & & Lower & .87575 \\
\hline 1 & Standard game & .83315 & .270199 & .79056 & .92000 \\
2 & Income decreases & .87449 & .287786 & .82897 & .86320 \\
3 & Income decreases & .81972 & .274915 & .77624 & .94284 \\
4 & Tax rate decreases & .90635 & .229918 & .86987 & .78773 \\
5 & Tax rate increases & .73484 & .334415 & .68195 & .80593 \\
6 & Penalty rate decreases & .75452 & .314261 & .70312 & .95470 \\
7 & Penalty rate increases & .92143 & .211016 & .88817 & .79351 \\
8 & Audit decreases & .72958 & .402893 & .66565 & 1.03124 \\
9 & Audit increases & .99203 & .255087 & .95282 &. \\
\hline
\end{tabular}

their income highest when the number of audit is increased. By contrast, they the average of reported to actual income ratio falls to its lowest point when the number of audit is decreased. This indicates that it is important for the tax office to ensure that the audits are maintained an adequate level.

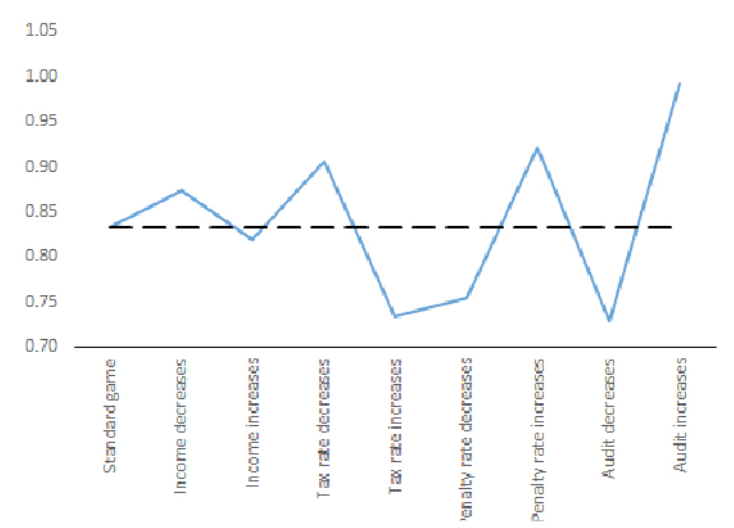

Figure 3 Game comparisons

Another factor that is important in improving compliance is penalty rate. activities. As such, it is important for the tax office to maintain their law enforcing activities such as gijzeling and audit adequately ((Septian, 2015 and Jati, 2015). This is because before a taxpayer is subject to penalty, that taxpayer has to be audited first. As audit is normally a result of a third party information, then information exchange undoubtedly plays a crucial role. However, it is important to note in this regard that increasing audit rate may in fact reduce compliance if the audit is aimed at already-compliant taxpayers (Gemmel and Ratto, 2012).

Another factor that is of interest is that an increase in income increases the amount of taxable income reported by the research participants. This provides an indication that the participants are generally risk taker as the more income they have, the more money they hide. This generally is consistent with what is reported by Juanda (2010) and Prasetyo 
(2011). For the tax office, this carries a consequence that their emphasis should beon high-income earners asthey notonly are willing to be con compliant, they can also afford to do so, possibly by obtaining tax advice from their consultants as seen in the Panama Papers.

Lastly, an increase in tax rate is followed by the action of the participants to reduce their reported income. Again this gives an indication of risk-taker participants. This is because as tax rate is increased, then the amount of benefit of reducing reported income (in the form of tax saving) is higher. The participants are apparently willing to take the additional risk to obtain more tax saving. Table 6 summarises these results.

Table 6 The effect of each factors on compliance

\begin{tabular}{|c|c|c|c|c|c|}
\hline \multirow[t]{2}{*}{ No } & \multirow{2}{*}{ Factor } & \multicolumn{2}{|c|}{$\begin{array}{l}\text { Direction of } \\
\text { change }\end{array}$} & \multicolumn{2}{|c|}{$\begin{array}{l}\text { Change of re- } \\
\text { ported income }\end{array}$} \\
\hline & & $\mathbf{U p}$ & Down & Up & Down \\
\hline \multirow{2}{*}{1} & \multirow{2}{*}{ Income } & $\checkmark$ & & & $\checkmark$ \\
\hline & & & $\checkmark$ & $\checkmark$ & \\
\hline \multirow{2}{*}{2} & \multirow{2}{*}{ Tax rate } & $\checkmark$ & & & $\checkmark$ \\
\hline & & & $\checkmark$ & $\checkmark$ & \\
\hline \multirow{2}{*}{3} & \multirow{2}{*}{ Penalty rate } & $\checkmark$ & & $\checkmark$ & \\
\hline & & & $\checkmark$ & & $\checkmark$ \\
\hline \multirow{2}{*}{4} & \multirow{2}{*}{ Audit rate } & $\checkmark$ & & $\checkmark$ & \\
\hline & & & $\checkmark$ & & $\checkmark$ \\
\hline
\end{tabular}

\section{Conclusion}

The experiment illustrated in this paper shows the following:

1. On average, the research participants report $83 \%$ of their actual taxable income to the tax office. This provides an indication that taxpayers in general do not fully report their taxable income to the tax office.

2. From several factors identified in the literature as having important effect on reported income, audit is indicated by the participant as having the highest effect on reported income followed by penalty rate and tax rate. This experiment also shows an evidence of risk-taker taxpayers indicated by the reduction of reported income as the participants' income or tax rate increases. High income earners are also shown to be prone to non-compliance activities.

From this experiment, it can be seen that it is important for the tax office to maintain the audit rate at an adequate level. The audits would potentially more effective if they are aimed at highincome earners as they are more likely to be involved in tax evasion or avoidance game.

None the less, it is to be noted that the experiment described in this paper is subject to some limitations. Firstly, most participants are students that act as taxpayers' proxy. Although it has been argued that the results generally are not significantly different, it will still be possible to improve the accuracy of the experiment if the participants constitute real taxpayers. Secondly, the participants of this experiment generally have limited exposure to business activities as they are either students or employees. Business owners generally are viewed having wider opportunities in evasion or avoidance activities. This unfortunately cannot be captured adequately in this paper. Future research endeavour would without a doubt be more fruitful if these limitations can be addressed.

\section{Reference}

Allingham, M. G., \& Sandmo, A. (1972). Income tax evasion: a theoretical analysis. Journal of Public Economics, 1(3-4), 323-338. doi:http://dx.doi. org/10.1016/0047-2727(72)900102.

Alm, J., McClelland, G. H., \& Schulze, W. D. (1992). Why do people pay taxes? Journal of Public Economics, 48(1), 21-38.

Arandse, J. (2010). Is the penalty system in South Africa an effective 
dan efficient deterrent to tax evasion? Dalam J. Mendel \& J. Bevacqua (Eds.), International Tax Administration: Building Bridges (pp. 61-81): CCH Australia Limited.

Becker, G. S. (1968). Crime dan punishment: an economic approach. The Journal of Political Economy, 76(2), 169-217.

Birch, A., T. Peters and A. Sawyer. (2003). New Zealanders' Attitudes Towards Tax Evasion: A demographic analysis. New Zealand Journal of Taxation Law and Policy 9, 65-109. Clotfelter, C., (1983). Tax Evasion and Tax Rules: an analysis of individual returns. The Review of Economics and Statistics 63 (3), 363-373.

Septian, Septian (2015). Tak Bayar Pajak, Siap-Siap Kena Sandera Ditjen Pajak. Retrieved from http://bisnis.liputan6.com/ $\mathrm{read} / 2262438 /$ tak-bayar-pajaksiap-siap-kena-sandera-ditjenpajak [Accessed May 18, 2017].

Druckman, J. N., \& Kam, C. D. (2011). Students as experimental participants: a defense of the narrow database. Dalam J. N. Druckman, D. P. Green, \& J. H. Kuklinski (Eds.), Cambridge Handbook of Experimental Political Science (pp. 41-57): Cambridge University Press.

Gemmell, N., and M. Ratto. (2012). Behavioral Responses to Taxpayer Audits: Evidence from Random Taxpayer Inquiries. National Tax Journal 65 (1), 33-58.

Giridharadas, A. (2010). A weird way of thinking has prevailed worldwide. Retrieved from http://www. nytimes.com/2010/o8/26/world/ americas/26iht-currents.html [Access May 18, 2017].

Gneezy, U., \& Rustichini, A. (2000). A fine is a price. The Journal of Legal Studies, 29(1), 1-17.
Gruber, J. (2012). Public Finance and Public Policy: Worth Publishers.

Jati, Gentur Putro (2015). Ditjen Pajak Bakal Lebih Galak Tahun Depan. Retrieved from http://www.cnnindonesia.com/ ekonomi/20150610204603 -7859184/ditjen-pajak-bakal-lebih-galak-tahun-depan/ [Access May 18, 2017].

Juanda, B. (2010). Ekonomi eksperimental untuk pengembangan teori ekonomi dan pengkajian suatu kebijakan. Scientific oration on IPB $47^{\text {th }}$ anniversary, Bogor. Retrieved from https://bbjuanda.files.wordpress.com/2010/09/270910_orasi-bambang-juanda1.pdf [Access May 18, 2017].

Laporan Hasil Pemeriksaan BPK RI atas Laporan Keuangan Keuangan Pemerintah Pusat Tahun 2015. (2016). Retrieved from http://www.kemenkeu.go.id/sites/default/files/ LKPP\%202015\%20Audited.pdf [Access May 18, 2017].

Libby, R., Bloomfield, R., \& Nelson, M. W. (2002). Experimental research in financial accounting. Accounting, Organizations dan Society, 27(8), 775-810. doi:http:// dx.doi.org/10.1016/So361 3682(01)00011-3.

Marriott, L. (2013). Using student subjects in experimental research: a challenge to the practice of using students as a proxy for taxpayers. International Journal of Social Research Methodology, 17(5), 503525. doi:10.1080/13645579.2013.7 86900 .

Marriott, L., Holmes, K., \& Randal, J. (2012). Experimental Methodologies in Tax Research. Paper dipresentasikan di Australasian Tax Teachers Association Conference, Sydney.http://pandora.nla.gov.au/ pan/23524/20121012-0251/syd- 
ney.edu.au/law/parsons/ATTA/ docs_pdfs/conference_papers/ Experimental_Methodologies_in_ Tax_Research.pdf [Accessed May 18, 2017].

Marriott, L., Randal, J., \& Holmes, K. (2013). Tax experiments in the real world. eJournal of Tax Research, 11(2), 216.

Prasetyo, Kristian Agung (2011). Pengujian tingkat kepatuhan pembayaran Pajak Penghasilan wajib pajak orang pribadi non-karyawan. Jurnal BPPK, 11, 23.

Slemrod, J., M. Blumenthal, and C. Christian. (2001). Taxpayer Response to an Increased Probability of Audit: Evidence from a controlled experiment in Minnesota. Journal of Public Economics 79, 455-483.
Tan, L.M. and C. Chin-Fatt. (2003). The Impact of Tax Knowledge on the Perceptions of Tax Fairness and Attitudes Towards Compliance. Asian Review of Accounting 8 (1), 44-58.

Vogel, J. (1974). Taxation and Public Opinion in Sweden: an interpretation of recent survey data. National Tax Journal 27 (4), 499-513.

Wahlund, R. (1993). Tax Changes and Economic Behavior: the case of tax evasion. Journal of Economic Psychology 13, 657-677. 